\title{
Comparison of the Views of School Administrators and Teachers Regarding Mathematics Lessons and Exams
}

\author{
Nurdan Özreçberoğlu ${ }^{1} \&$ Çağda Kıvanç Çağanağa ${ }^{2}$ \\ ${ }^{1}$ Institute of Graduate Studies \& Research, European University of Lefke, Lefke, Northern Cyprus \\ ${ }^{2}$ Department of Pre-School Teaching, European University of Lefke, Lefke, Northern Cyprus \\ Correspondence: Çağda Kıvanç Çağanağa, Department of Pre-School Teaching, European University of Lefke, \\ Lefke, Northern Cyprus. E-mail: ckivanc@eul.edu.tr
}

Received: March 28, 2017

Accepted: August 6, 2017

Online Published: August 22, 2017

doi:10.5539/jel.v6n4p336

URL: http://doi.org/10.5539/jel.v6n4p336

\begin{abstract}
Exams are a part of an important system which shows teachers and students the level of how much the topics have been covered. However, the level of suitability of using the same assessment tool for every subject is quite important when preparing these exams. Therefore, the importance of mathematics examinations has been addressed in this study. In this context, the difficulties encountered by teachers while preparing mathematics examinations and the issues regarding this were intended to be identified. A qualitative research method has been used in the research. The data has been collected by the interviews conducted with the school administrators and by the interview forms filled in by teachers. In consequence, it has been revealed that the schools and teachers have not been inspected for years and the basic deficiencies due to the primary education lead to problems in the mathematics exams performed associated with the secondary education with the arrangement of the regulation on passing exams every year.
\end{abstract}

Keywords: school administrators, mathematics teachers, mathematics exams

\section{Introduction}

Education system has a significant place in the development and progress of the society in a political and democratic environment (Özyılmaz, 2013). The government should be conscious of the duties which need to be performed especially with regard to the development of individuals in order to put the education system in order, as it is done in all countries (Eraslan \& Babadağ, 2015).

The necessity of mathematics for adults as well as pre-school children is emphasized since the $21^{\text {st }}$ century (Stipek, 2013). It is considered that it is important to pay attention to the input and process features in the affective area in order to use the mathematics, which cover the greatest part of the student life, at the time of requirement. On the other hand, the realization of learning will only be possible by means of positive affective attitudes which may be displayed towards behaviours targeted to be learned (Berkant \& Gençoğlu, 2015). It can be asserted that the communication of teachers with students, teachers' behaviours during the lessons, the prejudices of students and even the method and assessment tools used by teachers in fact affect the attitudes of students towards mathematics. The development of the students' perception of mathematics in a positive way is closely related to the assessment and evaluation tools which provide the feedback during the process. In this context, the teachers' deciding what to assess and with which aim will help the students to be familiar with the levels of the affective domain.

One of the concepts encountered as an indispensable part of the education system is without doubt the school. This is because the education provided and the activities carried out at schools aim to raise individuals who will contribute to the development of the society through unity, struggle and innovation. To that end, activities which will highlight the importance of mathematics, indicate its role in daily life and contribute to our development should take place during learning and teaching (MoE, 2013). School administrators are required in order for the schools to regularly discharge the responsibilities or follow the ways which are necessary to fulfil these aims. While fulfilling the aims, the school administrators should take the school to a higher level by benefiting from the improving branches of science and should define the mission of the school by taking into account the 
demands of those around (Bozkurt \& Aslanargun, 2015). Therefore, creating environments where students can concentrate on learning and teachers can teach the lesson efficiently is important.

It is said that the school administrators influence the life of the teacher and the student in general in terms of the leadership perception during their management at school for an effective school structure (Şişman, 2011). The influence of school administrators within a school will only be possible when the schools have a successful and effective structure (Sharma, 2012). Therefore, the aim of a good school administrator should be supplying the teaching materials and technological equipment necessary for the students' learning (Sarpkaya, 2010).

While the inspections to be made will contribute efficiently to the arrangement of the preparation of programs at the school, encouraging the students and teachers will be influential in increasing the level of success of the school (Kurt, 2013, p. 45).

In addition to the school administrators, it is also important for the teachers to be educators who research and develop themselves in the academic field by being aware of the innovations. In this context, not the seniority but the necessary and up-to-date knowledge one has should be taken into account in administration (Recepoğlu \& Kılınç, 2014).

A school administrator is also responsible for the allocation and use of the resources for the school, allowing the activities to be held, the cooperation among the employees, the necessary inspection and finding practical solutions to the problems which arise (Can, 2011).

Assessments and evaluations are considered important in order to determine whether the targets that need to be achieved by the behavioural change desired in teaching and learning programs have been achieved. This is why exams are held by arranging exam weeks twice in each term in the form of mid-term and final exams at schools of secondary education.

The primary assessment tools in the Turkish Republic of Northern Cyprus consist of three parts as written assessments, short-answer tests and multiple choice tests.

In addition to all these, taxonomies are highly important in education as they are used for variety in the differentiation of learning outcomes in cognitive domains. The Bloom's Taxonomy, particularly in its version renewed in 2001, is considered to be important in the preparation of the exam questions, which play an effective role not only in the classification of the variety of learning outcomes but also during the evaluation process. Bloom's Taxonomy takes into account the assessment and evaluation activities determined in accordance with the Ministry of Education (MoE).

The reason behind the assessment-evaluation is both enabling the students to observe their own success and also giving the families an idea about the level of education of their children. Moreover, they also provide information in order to make comments about the schools and the success of teachers at these schools, about the students to pass to an upper grade by common exams, their success or graduation degrees (Berkant \& Gençoğlu, 2015).

The questions prepared on the basis of the lessons of the weekly lesson schedule and the teaching program of that academic year are defined as exam questions (MoE, 2007/Art.6). Taking the targets to be achieved as basis in preparing the exams, they should be at a level to assess the capacity of the students in terms of making comments, analysing, critical thinking, guessing the results, solving questions, etc. (MoE, 2007/Art.7).

While preparing the questions for each level, care should be taken to ensure that questions are understandable, free of errors and prepared in line with the principles of validity, reliability and usefulness. One should also pay attention to ensure that the questions are arranged from simple to more complex and that the scores of questions are not randomly distributed. The exam paper should be calculated over 100 and the score of each question should be stated (Başol, 2015). Exam paper should be prepared in the format identified by the ministry. Furthermore, care should be taken to prepare questions appropriate for the level of students by the assessment tools to be used.

In this study, the opinions of mathematics teachers teaching at the $9^{\text {th }}$ grade level and school administrators in charge in those schools were received by the survey form and interviews under the present study. In this context, answers to the following questions have been sought in order to obtain the opinions:

Regarding the mathematics teachers;

1) Are there problems they are faced with while preparing exam questions?

2) Are they having difficulties due to student profiles or the textbooks while preparing the exams? 
3) Are there exam types which can provide alternatives to the standardized exam system?

4) Do they have suggestions to increase the students' success in exams?

5) What are their ideas about the preparation of the exam together with the teacher of the other class?

Regarding the school administrators;

1) What kind of system is implemented for mathematics exams? What are their views regarding the suitability of these exams for the level of students?

2) What are their views about the assessment tools used by the mathematics teachers?

3) What are their views about the assessment and evaluation units?

4) What are their views about increasing the student success?

The different types of high schools addressed in the research include the regular, private and vocational high schools, which are educational institutions where the secondary school and high school level education is provided jointly. Of these schools, only the vocational high schools are educational institutions providing merely the high school level education. In that connection, the views of mathematics teachers teaching at different types of high schools as well as those of school administrators regarding the mathematics exams have been obtained. The views on the mathematics exams have been obtained by taking into account the curriculum related to the mathematics for the $9^{\text {th }}$ grade. It is indicated that the curriculum especially includes subjects like algebra, probability, polynomial and trigonometry so that the individuals receiving high school level education at the $9^{\text {th }}$ grade can reason, use mathematical communication, associate mathematics to daily life, interpret, analyse and think in a critical way (MoE, 2013). It can also be said that the content of the curriculum related to the mathematics for the $9^{\text {th }}$ grade is the same in all high schools in spite of being of different types.

\section{Method}

In this research, the interview as one of the qualitative research methods and phenomenological method as one of the qualitative research methods were preferred. They have been defined as studies which aim to reveal and interpret personal perceptions towards any phenomena (Yıldırım \& Şimşek, 2011).

\subsection{Population-Sample}

The population of the research comprise school administrators and mathematics teachers teaching at the $9^{\text {th }}$ grade level at the high schools of secondary education in the TRNC in the fall term in the academic year 2015-2016. The sample of the research consists of 15 mathematics teachers and 4 school administrators who were randomly selected. The teachers forming the sample of the research works at different types of schools (regular, private and vocational) in Morphou, Nicosia, Kyrenia, Iskele and Lefka. A maximum variety sample type has been used due to the selection of schools of different types and regions. Using such kind of sample allows a high level reflection of the types of individuals by determining the side of the individuals about the studied subject. The school administrators were determined as people working at different types of schools in Guzelyurt and Lefke as the choice of identified regions is problematic in terms of time and ease of access.

10 of the mathematics teachers who participated in the research are female and 5 are male with ages varying between 31-52. As for the level of education of these teachers, it has been observed that 1 of the teachers completed the postgraduate education; 1 is still at the postgraduate level and the other 13 completed the undergraduate education. All the school administrators who participated in the research are male with ages varying between $48-57$.

\subsection{Data Collection}

A structured survey form was applied to the teachers for the collection of data. With the prepared survey form, it has been aimed to take views of teachers about finding solutions to the problems they encounter regarding the mathematics exams they prepare for the $9^{\text {th }}$ grade, their suggestions about the standardized exam system and about increasing the success of students. In the preparation stage of the survey form, the opinions of two academics, an assistant professor doctor and a doctor from the fields of mathematics education and assessment-evaluation, were taken and necessary arrangements were made. The interview method was preferred in order to collect the data on the views of school administrators. In the interview method, the views of school administrators were taken about the way particularly the $9^{\text {th }}$ grade mathematics exams were prepared, their level of appropriateness and the assessment-evaluation methods used. The responses were recorded on a voice recording device with their consent. 


\subsection{Analysis of Data}

Content analysis was carried out for the analysis of the data. By conceptualising the data obtained by the content analysis, it is aimed to create the themes defining the data by arranging these concepts (Yıldırım \& Şimşek, 2013). The responses obtained for each question in the interview form of teachers were arranged and the themes were created under determined codes. Regarding the responses given by the school administrators, the data obtained by recording machine were coded and the opinions were provided in this way.

\section{Findings}

Table 1. Views of teachers regarding the open-ended questions

\begin{tabular}{|c|c|c|c|}
\hline Items & Views & f & $\%$ \\
\hline \multirow{4}{*}{$\begin{array}{l}\text { Are there any problems you } \\
\text { encounter while preparing } \\
\text { exam questions? If yes, what } \\
\text { are they? }\end{array}$} & No & 7 & 46.67 \\
\hline & Student profile level & 3 & 20.00 \\
\hline & Preparing question suitable for the student levels & 2 & 13.33 \\
\hline & Suitability of commonly prepared questions for all the classes & 3 & 20.00 \\
\hline \multirow{7}{*}{$\begin{array}{l}\text { Do you have problems while } \\
\text { preparing exams due to the } \\
\text { student profile or textbook? }\end{array}$} & No & 4 & 26.67 \\
\hline & Yes & 2 & 13.33 \\
\hline & The lack of homogeneous distribution of the class in terms of level of students & 2 & 13.23 \\
\hline & $\begin{array}{l}\text { The lack of including difficult questions in identifying the question levels according } \\
\text { to the student profile. }\end{array}$ & 3 & 20.00 \\
\hline & Inappropriate textbooks for the student profile due to being Turkey based textbooks & 1 & 6.67 \\
\hline & Insufficiency of the textbook content & 2 & 13.33 \\
\hline & Inappropriate textbooks for vocational high schools & 1 & 6.67 \\
\hline \multirow{4}{*}{$\begin{array}{l}\text { Are there exam types to be } \\
\text { alternative to the standardized } \\
\text { exam system? If yes, what are } \\
\text { they? }\end{array}$} & No & 6 & 40.00 \\
\hline & Increasing the number of exams by doing exams at the end of each topic & 5 & 33.33 \\
\hline & $\begin{array}{l}\text { Implementation of different types of exams (applied, verbal, project) apart from the } \\
\text { written exams }\end{array}$ & 3 & 20.00 \\
\hline & Renewal of assessment-evaluation system & 1 & 6.67 \\
\hline \multirow{8}{*}{$\begin{array}{l}\text { Do you have any } \\
\text { recommendations in order to } \\
\text { increase the student success in } \\
\text { the exams? }\end{array}$} & Preparing the books oriented for the exams & 2 & 13.33 \\
\hline & Carrying out activities increasing the interest in the lesson & 1 & 6.67 \\
\hline & Increasing the lesson hours of applied lessons & 1 & 6.67 \\
\hline & $\begin{array}{l}\text { Exams should be done at the end of each topic and the received scores should } \\
\text { contribute to the general mark }\end{array}$ & 6 & 40.00 \\
\hline & Doing technology aided mathematics lessons & 1 & 6.67 \\
\hline & $\begin{array}{l}\text { Increasing the interest of students in the lessons with the change of pass/fail system } \\
\text { (they should not think I will pass in any case) }\end{array}$ & 2 & 13.33 \\
\hline & The current number of students should be decreased & 1 & 6.67 \\
\hline & Exams should be done during the lessons & 1 & 6.67 \\
\hline \multirow{5}{*}{$\begin{array}{l}\text { What are your views regarding } \\
\text { the preparation of the exam } \\
\text { together with the teacher of the } \\
\text { other class. }\end{array}$} & It is more suitable to generate equivalence and justice in terms of education. & 4 & 26.67 \\
\hline & It is more suitable in terms of subject integrity. & 3 & 20.00 \\
\hline & Not appropriate due to the differences in the level of students in the class & 2 & 13.33 \\
\hline & $\begin{array}{l}\text { Not appropriate for classes which have area (Turkish-maths, social, science, etc.) } \\
\text { differences }\end{array}$ & 1 & 6.67 \\
\hline & It should be done that way & 5 & 33.33 \\
\hline
\end{tabular}


As the table suggests;

1) Regarding the item "Did you encounter any problems while preparing the exam questions? If yes, what are they?" which is related to teachers, it has been observed that 7 teachers did not encounter any problems, 3 teachers encountered problems in terms of student profile capacity, 2 teachers had problems in choosing the appropriate question according to the level of students while preparing exams and 3 teachers had problems in terms of the appropriateness of the exams they jointly prepared to all the students in all classes. Having a look at the previous research conducted on this, it has been observed in the study of Yanık, Bağdat, Gelici and Taştepe (2014) that they addressed the problems encountered by the mathematics teachers in the first years of their profession. It has been seen that these teachers encountered problems in assessment and evaluation topics as well as the methods and techniques of teaching and the preparation of lessons. It has been observed the reason of these problems is the education received in undergraduate studies.

Teachers with the codes T2 and T13 used the statements below to express their views regarding the encountered problems in preparing the exam questions.

"We are having problems as the student profile limits certain types of questions that we want to ask."

"We are encountering certain types of problems due to the student profile."

2) Regarding the item "Do you have problems while preparing exams due to the student profile or textbook?", 4 of the teachers stated that they did not have any problems. However, while 2 of them stated that they had difficulties, they could not express the kind of difficulty they experienced. It was observed that 2 of the teachers stated the problems they encountered due to lack of homogeneous distribution in the class in terms of the level of students and 3 of them mentioned the problems they had as a result of failing to include difficult questions in determining the appropriate levels of question for the student profile. Also, 1 teacher expressed the problem encountered due to the inappropriateness of the textbooks for the student profile as they were prepared by taking as a basis the Republic of Turkey. On the other hand, it was also observed that 2 teachers mentioned the problems they had as the content of the book was not adequate and 1 teacher stated that the textbooks were not appropriate for vocational high schools.

In some studies researching the problems encountered in teaching mathematics, it has been observed that the problems which were encountered due to the class equipment, teachers, students, program and textbooks were included. Among these studies, Durmuş (2004) stated that the reason of students' perceiving mathematics as difficult is due to the deficiency in motivation and the abstract way of teaching the topics. Baykul (2003) linked the problems encountered in mathematics lessons with the insufficient in-service trainings of teachers and inspectors, the insufficiency of lesson programs and textbooks, the inability to make students love mathematics, the lack of clarity about why mathematics is taught, the lack of self-improvement of teachers in their fields, the lack of interest of students due to the complexity of the mathematics language used and with insufficient resources. Ojimba (2012) stated that the main problems encountered in mathematics are the crowded classes, the insufficiency of laboratories at schools and the negative attitude of students towards mathematics. Onat and Aksu (2014) investigated the mathematics books in terms of the necessity of their contents to be related with the daily life.

Teachers coded T2, T17 and T8 used the statements below regarding the difficulty of preparing exams due to the student profile or textbooks.

"We are not happy with the weak calculation skills of our teachers and the expression styles of textbooks."

"The difficulties in certain topics are due to the publishing of the textbooks as focused on Turkey."

"The low knowledge levels of students render it difficult to determine the levels of questions."

3) Consequent to the examination of the data obtained from the table regarding the item "Are there exam types to be alternative to the standardized exam system? If yes, what are they?", it has been observed that 6 teachers did not suggest any alternatives. While 5 teachers stated that they believe exams should be held at the end of each topic and the number of exams should be increased, 3 teachers believe that different exams should be done by using different types of exams apart from the written exams. 1 of the teachers, on the other hand, mentioned that the assessment and evaluation system should be renewed. No similar studies were found in the conducted literature review.

The teachers coded T5, T1 and T14 made the statements below regarding the alternatives they would suggest to the standardised exam system. 
"Making quizzes in between exams will enable the obtained scores to be effective as well as refresh the knowledge of students."

"The success of the students should not only be assessed by written exams but also by evaluating the applied exams added to the system."

"I think mid-topic exams can be done at the end of each topic."

4) Regarding the item "Do you have any recommendations in order to increase the student success in the exams?", 2 of the teachers thought that the textbooks should be prepared for the exams, 1 teacher believed that activities increasing the interest in the lesson should be carried out and 1 teacher thought that the hours of applied lesson should be increased. 6 teachers highlighted that exams should be done at the end of each topic and contribute to the general score of students. 1 of the teachers believed that the mathematics lessons should be technology aided and 2 teachers thought that the pass/fail system should be changed in order to increase the interest of students in the lessons so that they would not believe they would pass in any case. Also, 1 of the teachers believes that the current number of students should be decreased, and the exams should be done during the lesson.

Having a look at the similar studies in the field, Başokcu and Oğuz (2014) compared the structured grid and multiple choice tests as alternative assessment and evaluation tools in determining the student success. On the other hand, Peker and Mirasyedioğlu (2003) investigated the relationship between the attitude scores and success scores of students studying $t$ the ninth grade towards mathematics. Dursun and Dede (2004) stated in their study that the teaching strategies are important for the increase of the student success. Furthermore, it has been stated that using the teaching strategies and techniques used in the class with the traditional methods by teachers may lead to certain problems. At the same time, Dursun and Dede (2004) emphasized the importance of learning the abstract language and experience in order to increase the success in mathematics. In order to increase the success of students in mathematics, Mumcu and Aktaş (2012) expressed that the interest in this field can be increased by informing the students about the places where mathematics can be used, rather than only being a lesson to be passed.

The teachers coded as T10, T8 and T2 made the statements below as suggestions to increase the success of students in exams:

"I believe that some parts of the lessons should be visual and classes specific to mathematics should be arranged in order to make mathematics more loveable."

"I believe that the success of the students can be affected positively by increasing course hours and solving more questions."

"Decreasing the current number of students in classes will increase the student success."

5) Regarding the item "What are your views regarding the preparation of the exam together with the teacher of the other class?", 4 teachers stated that a common exam should be prepared in order to generate equivalence and justice in education and 3 teachers stated that a common exam should be prepared in order for the integrity of topics. On the other hand, 2 teachers expressed that it is not appropriate to prepare a common exam due to the differences in the level of students in classes and 1 teacher expressed that it is not appropriate to prepare a common exam due to the difference in areas. It was also observed that 5 teachers mentioned their view that exams should be prepared jointly with the teachers of the other class.

In a research made by Arı and İnci (2015) in a similar vein, it has been stated that the consistency between the exams in terms of content, process and evaluation would allow measuring to what extent the exam to be held would serve its purpose.

Teachers coded T11 and T3 expressed their views on the preparation of the exam together with the teacher of the other class as follows:

"The topics taught and the questions solved during the terms should be parallel. In connection therewith, preparing the exam questions jointly is important in terms of equality."

"It would be better to prepare the exams differently for some classes due to the level of students and since we are not teaching the topics at the same level in each class."

The questions asked to the school administrators and their responses were recorded with a voice recorder during the interviews by taking the consent of the speakers. The recorded responses were coded under certain categories according to their similarity and themes were formed. In this context, the determined code and themes are as 
given below. In addition, it was aimed to provide some of the opinions of the school administrators through "direct transfer" technique by numbering them between 1 and 4 with high school types being mixed. The views of the school administrators were thus divided into themes as follows:

1) About the system applied for the mathematics exams and the suitability of these exams for the student levels.

- Doing two exams in one academic term as mid-term exam and final exam

- Preparation of exams by the freewill of teachers

- Identification of the success of students by the marking system

- Assessment of exams by school administrators only in terms of duration and scoring

- Insufficiency of the school administrators in terms of the level of students in the assessment needing expertise

- Sending copies of each exam to the assistant directorate, the relevant ministry and the supervision office

- Having the exams in the exam type determined by the administrators

- Paying attention to the preparation of exams commonly in accordance with the integrity structure and relevant regulation

2) About the assessment tools that mathematics teachers use.

- They are in the type determined by school administrators

- Similarity to the university preparation exam to prepare for the universities

3) About evaluation and assessment and units which may be set up.

- Lack of a specific mechanism during the existing measurements and assessments by teachers

- Carrying out the evaluation according to the answer sheet determined by teachers

- Implementation of the bell curve according to the failure in the general status of the exam

- Facilitation of the work of teachers by such units to be formed

- Checking the appropriateness of question levels and types according to the topics

4) About increasing the student success.

- Carrying out the necessary inspection by inspectors

- Informing the ministry about the information and issues obtained by the cooperation of teachers

- Replying back to the statements received by the ministry

- Providing courses at schools

- Removing the effect of politics in education on the grade passing system

- Redesigning the primary education curriculum

- Providing the basic education to be given in the primary education without taking into account the college admission exams

- Rearranging the programs according to the types of high schools

1) The opinions of school administrators were taken about the system applied for the mathematics exam and the suitability of these exams for the level of students. In the context of the obtained opinions, it has been stated that the textbook for mathematics determined by the Ministry of Education is used in the class, teachers prepare annual lesson plans on the basis of the criteria determined in the law and regulations and they determine weekly lesson plans based on these criteria. The school administrators stated that in addition to carrying out the lessons according to the prepared schedules, a total of two exams were made as mid-term and final-exams, the students were determined as successful or unsuccessful according to the grading system as a result of the exams they have, which are prepared by the teachers themselves. However, in line with the decisions taken every year due to the political structures, they also stated that many problems are encountered due to having unsuccessful students passed to a higher grade.

2) The exam types and the assessment tools used are inspected by the school administrators. The school administrators stated that it is the duty of the inspectors of the ministry to check whether the duration is usable, whether the teachers prepare the exams within the stated rules, the suitability of questions to the curriculum or the suitability of the level of questions to the level of students. In order to increase the success of students about 
which the teachers are targeted to be inspected, one copy of each exam done is also sent to the relevant ministry, the supervision office and the assistant director of the school (Baffour-Awuah, 2011).

3) As a result of the conducted interview, it has been identified that the school administrators aim to provide equivalence in exams prepared commonly by making different teachers teach in different classes at schools. Similarly, the study of Arı and Inci (2015) is parallel with this study as it demonstrates that common exams are done which include the concepts that students learn and the teachers work in collaboration in order to provide better results.

4) The opinions of school administrators about the assessment tools that the mathematics teachers use were taken. As per the views obtained, school administrators stated that the joint decision taken together with the teachers is that the mathematics exams would be prepared in the classical style. In addition, the school administrators working at regular and private high schools stated that $50 \%$ of the exams done in the second term are multiple choice and the rest is classical, depending on the will of teachers. On the other hand, considering the students preparing for the university in this type of schools, it has been stated that the type of questions and assessment tools can be applied according to this type of exam.

5) Measuring and improving the quality of education through assessment and evaluation practices are among the primary aims (Balc1 \& Tekkaya, 2000). In this connection, teachers working at schools are deemed to know how to prepare or hold the exams.

6) School administrators stated that the applicable assessment and evaluation procedure was performed by the teachers and the evaluation part was carried out again by the teachers according to the answer sheet which was formed. As a result of the interviews conducted with the school administrators, it has been ascertained that a system where a bell-curve could be applied depending on the teacher in case of general failure within the class was present.

7) Having a look at the views of school administrators on the assessment and evaluation units, it has been observed that the school administrators believe that there are more important issues than this in education such as serious deficiencies and lack of necessary inspections. Sarıbaş and Babadağ (2015) highlighted the insufficiency of the experts in the education administration in their study. It has been observed that the school administrators have problems due to this reason and they consider establishing such a unit at schools positively. They have also stated that they believe that the teachers at schools will have easier work to do in such a system to be established. Moreover, the school administrators expressed that they believe establishing such a system will be of great importance in checking the suitability of level and type of questions.

8) Finally, in line with the obtained data from the opinions of the school administrators on increasing the student success, they stated that cooperation of branches, transfer of the information obtained as a result of this cooperation and the precautions to be taken by the ministry by evaluating this information may increase the student success. Accordingly, the demanded success will be achieved by carrying out the necessary inspections by the ministry. In parallel with this, Aslanargun and Tarku (2014) analysed the inspection regulation applied in England and the United States (USA) and revealed in their study that this inspection would be effective in generating student success as teachers make observations in the class and assess the class management by analysing it. On the other hand, Berkant and Gençoğlu (2015) emphasized in their study that the school administrators are responsible for establishing cooperation among teachers and highlighted the importance of cooperation of teachers in producing solutions to the encountered problems by helping the school administrators.

9) In addition, administrators put forward the necessity of stopping the change in the regulation on passing the exams in the politics in education. Due to this reason, students ignore the understanding of discipline as they feel relaxed that they will pass the exams in any case.

10) School administrators stated that the primary education known as the basic education is highly important for students in reflecting their knowledge. They also stated that the primary education curriculum based on a parrot-system affects the student success negatively. Similarly, Berkant and Gençoğlu (2015) identified in their study that students believed that they would not use mathematics in their daily life and thus intended to memorize mathematics in order to find solutions.

11) As per the conducted interviews, school administrators consider that the college admission exams right after the primary education affect the psychology of students adversely and cause problems associated with fundamental knowledge. They also stated that the students are provided with a very high level of information and directed towards this exam completely, which in fact causes lack of fundamental knowledge. Moreover, it has been stated that another factor of the failure in students is not being able to improve problem-solving skills. 
Due to this reason, the necessity of redesigning the primary education curriculum has been revealed in order to increase the student success. Berkant and Gençoğlu (2015) also stated in their study that the difficulty of curriculum lead to the failure of students and to a decrease in their motivation. In addition, the school administrators noted the necessity that the programs should be rearranged according to different types of high schools.

\section{Results and Recommendations}

\subsection{Results}

The results have been divided into two parts as the survey forms applied to the teachers and the interviews conducted with the school administrators.

\subsubsection{About Teachers}

Consequently, it has been sought to determine to what extent were the skills which should have been upskilled during the mathematics education at the $9^{\text {th }}$ grade level through the exams made by taking into account the curriculum. To that end, views were obtained as to the problems encountered, things to do to increase success and determination of factors which are considered to be inadequate.

According to the data obtained from the survey forms applied to the teachers, it has been found out that due to the deficiencies in the basic education of $9^{\text {th }}$ grade students, the teachers encountered problems in determining the question types and the level of suitability of the topics while preparing the questions. In their study, Güler, Özdemir and Dikici (2012) have compared the placement tests and the exam questions prepared by mathematics teachers of primary schools. The study dealt with whether the teachers included questions at the lower and higher cognitive level. Also, holding of seminars was suggested in order to inform the teachers on question preparation techniques. On the other hand, the teachers who noted the necessity to carry out teaching in a parallel way in different classes, which is thought to contribute to the motivation of students in terms of integrity and equivalence stated that they agree on the view that exams should be prepared jointly. Contrary to this view, some teachers stated that they knew their students best and thus needed to evaluate the exams by their own will. The teachers who believe that the textbooks should be rearranged for different types of high schools in order to increase the student success stated the necessity of increasing the number of course hours to be able to spare some time for question-solving. In a similar study, the views of teachers on the application of activities contained in mathematics textbooks as well as the devising of events were addressed (Bozkurt \& Kuran, 2016). Consequent to the literature review made, it can be said that the attitude towards the course (Duman, 2006; Savaş, Taş, \& Duru, 2010; Turpçu, 2014), using methods which can provide opportunities to improve thinking skills (Dane, Dudu, \& Balk1, 2009) and developing abilities to create problem-solving skills should be given significance in order to increase the success of students in mathematics (Yıldız, 2016).

In line with the conducted interviews, it has been found out that the teachers believed that the success can be increased by using alternative assessments and evaluations with respect to the exams held for the $9^{\text {th }}$ grade so as to contribute to the students. Similarly, Gür and Seyhan (2016) noted in their study the necessity of resorting to new teaching and learning models in order to instil in the students the love for mathematics and to facilitate achievement.

\subsubsection{About School Administrators}

A number of data were also obtained after the interviews conducted by the school administrators. However, consequent to the data obtained, the view that the assessment and evaluation in areas of expertise are only inspected by administrators under the present education system and at that point the administrators remain incapable has emerged. Given this situation, it is significant that a commission be set up for the teachers to develop new teaching techniques, the preparation of questions and the enhancement of students' success as well as training school administrators with in-service trainings as a contribution to course inspections (Tombul \& Baysülen, 2017).

The administrators, who also argue that the schools have not been inspected by the ministry for long years highlighted that unsuccessful students were passed to a higher level with the ministry's making arrangements on the regulation on passing exams every year through political influence. Also, the administrators believed that another factor underlying the failure of students was due to not making the students acquire the skills and knowledge which should have been provided in basic education. According to the school administrators, factors like not inspecting teachers, the dominance of politics and making unsuccessful students pass play a significant role in the decrease of the quality of education in our country. 
In this system highly based on memorising, the school administrators believed that checking whether the curricula are compatible with our geography and comparing them with other countries if necessary is important. They highlighted that designing the level of difficulty in determining the programs and discussing the level these should be provided would contribute to education. In particular, it is generally believed that arranging programs specific to vocational high school was also a necessity and this would prevent nonchalance on the part of the students. In the preparation of quality textbooks, care should be taken for the level of students as well as proper arrangement and comprehensibility of subjects (Altun, Arslan, \& Yazgan, 2004). Finally, school administrators mentioned problems encountered in education and highlighted the fact that the skills of responsibility assumption as well as sense of discipline were lost in students who were taken to an upper level through political influence.

\subsection{Recommendations}

The recommendations of the research were expressed under three categories as teachers, school administrators and the ministry.

\subsubsection{Recommendations Regarding Teachers}

Care should be taken to include solving of problems by sticking to the completion of the curriculum. In cases where this cannot be done, free courses within the school should be organized by considering that these would improve the motivation of students and affect their success positively. The mathematics teachers should take into consideration the level of students when preparing the questions and pay attention to informing the students in advance while determining the assessment methods appropriate for the topics.

\subsubsection{Recommendations Regarding School Administrators}

With the establishment of assessment and evaluation units at schools, the group teachers will be able to inspect the mathematics exams prepared at schools which in turn would allow for the evaluation of the appropriateness of the exams for the level of students. It is considered that such a system would also contribute to student success. It is furthermore deemed that the cooperation of mathematics teachers in determining the assessment tool to be used would be beneficial in terms of motivating the students.

\subsubsection{Recommendations Regarding the Ministry}

The ministry should increase the number of its inspectors and carry out the necessary inspections to make the teachers think that they can be inspected any time and thus wish to improve themselves consistently and be willing and ready to increase student success.

The inspectors should be allowed to make observations continuously and regularly. Also care should be taken to evaluate teachers from different perspectives by means of conducting certain polls in order to have an idea about the narrative style of the teacher and the assessments-evaluations he/she performs.

\section{References}

Altun, M., Arslan, Ç., \& Yazgan, Y. (2004). A Study on the Usage of High School Textbooks and Its Frequency. Uludağ University Education Faculty Journal, 17(2), 131-147.

Arı, A., \& İnci, T. (2015). Evaluation of Common Exam Questions about the Eighth Grade Science and Technology Class. Uşak University Journal of Social Sciences, 8(4).

Aslanargun, E., \& Tarku, E. (2014). Expectations of Teachers from Inspectors in Terms of Professional Guidance and Counselling. Education Management in Theory and Practice, 20(3), 281-306.

Baffour-Awuah, P. (2011). Supervision of instruction in public primary schools in Ghana: Teachers' and headteachers' perspectives (A dissertation submitted to the graduate studies of Murdoch University in partial fulfilment of the requirements for the Degree of Doctor of Education). School of education, Murdoch University, Australia.

Başokçu, E., \& Oğuz, E. (2014). Comparing the grid and multiple choice tests in determining the mathematics success. XI. In National Science and Mathematics Education Congress Abstracts Booklet (p. 12).

Başol, G. (2015). Assessment and Evaluation in Education Pegem publishing. Ankara.

Baykul, Y. (2003). Teaching mathematics and related issues. Retrieved from http://www.matder.org.tr/index.php?option=com_content\&view=article\&id=44:matematikogretimi-ve-bazi -sorunlar-\&catid=8:matematikkosesi-makaleleri\&Itemid $=172$ 
Berkant, H. G., \& Gençoğlu, S. Ş. (2015). Opinions of Mathematics Teachers Regarding the Mathematics Education in Different Types of High Schools. KSÜ Journal of Social Sciences, 12(1), 194-217.

Bozkurt, A., \& Kuran, K. (2016). Analysis of Teachers' Experiences of and Views on the Implementation of Activities in Mathematics Textbooks and Activity Devising. Ege Education Journal, 2(17), 377-398.

Can, N. (2011). Factors Affecting the School Organization (p. 49). Pegem Academy Publishing: Ankara.

Dane, A., Kudu, M., \& Balk1, N. (2009). Factors Affecting Mathematics Success Adversely As Per the Perceptions of High School Students. Erzincan University Journal of the Institute of Science, 2(1), 17-35.

Duman, A. (2006). Evaluation of the Factors Affecting the Mathematics Success of Primary School Students in Terms of Students and Teachers (Example of the Province of Eskişehir, Post-graduate Thesis). Osmangazi University, Eskişehir.

Dursun, Ş., \& Dede, Y. (2004). Factors affecting the success of students in mathematics: Opinions of mathematics teachers. Gazi Faculty of Education Journal, 24(2), 217-230.

Eraslan, L., \& Babadağ, G. (2015). Basics of Educational Law. Introduction to Science of Education (In Press) evolution? Early Education and Development, 24(4), 431-535.

Güler, G., Özdemir, E., \& Dikici, R. (2012). The Comparative Analysis of Examination Questions of Primary Education Mathematics Teachers and SBS Mathematics Questions in Accordance with Bloom's Taxonomy. Erzincan University Education Faculty Journal, 14(1).

Gür, H., \& Seyhan, G. (2016). The Influence of Active Learning on Student Success in $7^{\text {th }}$ Grade Primary Mathematics Education. Ballkesir University Journal of Institute of Science, 8(1), 17-27.

KURT, A. A. (2013). Scientific Research Methods. Eskişehir: Anadolu University Publication No: 2750, Open University Faculty Publication No: 1708.

MoE. (2007a). Secondary Education Institutions Student Selection and Placement Exam Guide.

MoE. (2007b). Transition System to Secondary Education Guide Book (Education Technologies General Directorate Publications). Ankara.

MoE. (2013). Secondary education mathematics lesson (9th, 10th, 11th and 12th Grades) education program (p. VII). Ankara: MoE Publications.

Mumcu, İ., Mumcu, H., \& Aktaş, M. C. (2012). Mathematics for vocational high school students. Amasya University Faculty of Education Journal, 1(2), 180-195.

Niyazi, C. (2011). Factors Affecting the School Organization (p. 49). Pegem Academy Publishing, Ankara.

Ojimba, D. P. (2012). Strategies for teaching and sustaining mathematics as an indispensable tool for technological development in Nigeria. Mediterranean Journal of Social Sciences, 3(15), 74-79.

Özyılmaz, Ö. (2013). Turkish National Education System Problems and the Search for a Solution (4th ed.). Ankara: Pegem Akademi.

Peker, M., \& Mirasyedioğlu. (2003). Relationship between the attitude of ninth grade students towards mathematics and their success. Pamukkale University Faculty of Education Journal, 2(14), 157-166.

Recepoğlu, E., \& Kılınç, A. Ç. (2014). Selection and Placement of School Administrators in Turkey, Current Problems and Solution Recommendations. Turkish Studies-International Periodical for The Languages, Literature and History of Turkish or Turkic, 9(2), 1817-1845.

Sarıbaş, S., \& Babadağ, G. (2015). Basic Education Problems. Anatolian Education Leadership and Education Journal, 3(1), 18-34.

Sarpkaya, R. (2010). Turkish Education System and School Management (Improved 2nd ed.). Ankara: Anı publishing Seçkin Publishing House.

Savaş, E., Taş, S., \& Duru, A. (2010). Factors Affecting Student Success in Mathematics. İnönü University Journal of Education Faculty, 11(1), 113-132.

Sharma, S. (2012). Instructional leadership model through Asian principals' perspectives. International Conference on Education and Management Innovation IPEDR, 30, Singapore.

Şişman, M. (2011). Teaching Leadership (3rd ed.). Ankara: Pegem Akademi, Technologies General Directorate Publications, Ankara. 
Stipek, D. (2013). Mathematics in Early Childhood Education: Revolution or Evolution? Early Education \& Development, 24(4), 43. https://doi.org/10.1080/10409289.2013.777285

Tonbul, Y., \& Baysülen, E. (2017). Evaluation of the Amendment of Regulations on Course Inspection Based on the Views of Education Inspectors, School Administrators and Teachers. Primary Education Online, 16(1).

Turpçu, L. (2014). Reasons for the Failure of High School Students in Mathematics Course (The Example of the Province of Adana) (Post-graduate thesis). Okan University, İstanbul.

Yanık, H. B., Bağdat, O., Gelici, Ö., \& Tatepe, M. (2014). Opinions of Secondary School Mathematics Teachers on the Problems They Encountered During the First Years. XI. In National Science and Mathematics Education Congress Abstracts Booklet (pp. 537-538).

Yıldırım, A., \& Şimşek, H. (2013). Qualitative Research Methods in Social Sciences. Ankara: Seçkin Publishing.

Y1ldiz, C. (2016). Investigation of Mathematics Teachers' Views About Improving Problem-Solving Skills. International Conference on Education in Mathematics, Science and Technology (ICEMST-2016), Ersan Resort and Spa, Muğla.

\section{Copyrights}

Copyright for this article is retained by the author(s), with first publication rights granted to the journal.

This is an open-access article distributed under the terms and conditions of the Creative Commons Attribution license (http://creativecommons.org/licenses/by/4.0/). 